\title{
Attitude of future healthcare professionals towards food supplements
}

\author{
EWELINA WIERZEJSKA ${ }^{1}$, JANA KRZYSZTOSZEK ${ }^{2}$, MONIKA KARASIEWICZ ${ }^{1 *}$
}

\author{
${ }^{1}$ Laboratory of International Health \\ Department of Preventive Medicine \\ Poznan University of Medical Sciences \\ Święcickiego 6 \\ 60-781 Poznan, Poland \\ ${ }^{2}$ Department of Didactics of Physical Activity \\ University School of Physical Education \\ Królowej Jadwigi 27/39 \\ 61-871 Poznan, Poland
}

*corresponding author: phone: +4861 85465 75, fax: +4861 85465 78, e-mail: mkarasiewicz@ump.edu.pl

\section{Summary}

Introduction: The use of dietary supplements has been observed for many years. Unfortunately, the status of food supplements and main differences between these and drugs remain unknown to most consumers.

Objective: The purpose of the study was to analyze the opinions of future healthcare professionals on dietary supplements, their behavior concerning food supplementation, as well as their knowledge on the safety of these products.

Methods: The survey was conducted among 354 future healthcare professionals, using a questionnaire composed of 21 items exploring demographic characteristics, knowledge of supplements, reasons for the use of dietary supplement, and recall of the use.

Results: All respondents knew that the purpose of using these products is supplementation. A vast majority of respondents (83.9\%) thought that a diet with no supplementation is possible or probably possible. $49.4 \%$ of respondents $(n=175)$ declared taking food supplements. The most commonly used ones $(68.6 \%)$ were products recommended during illness and used to improve the condition of skin, hair, and nails. Moreover, dietary supplements mentioned by students included those containing herbal ingredients, such as: Equisetum arvense, Allium sativum, Panax ginseng, and Ginkgo biloba. Most of respondents buy dietary supplements at pharmacies (89.14\%). 
Conclusions: Use of dietary supplements is widespread among students. Future healthcare professionals have a better knowledge on food supplementation than population of Poland in general, however, they still need good education in this matter.

Key words: food supplements, health care professionals, herbal substances

\section{INTRODUCTION}

Dietary supplements gained high popularity for many years. This is mostly associated with trends of healthy lifestyle, supplementation and beauty care. In the opinion poll by SW Research Market and Opinion Research Agency conducted in 2017 on a representative group of over 800 respondents, $72 \%$ of Poles admitted using dietary supplements, and nearly half of them (48\%) used them regularly [1]. In 2015, Poles spent PLN 3.5 billion on dietary supplements, and bought nearly 190 million packages of these products [2] which means a statistical average of six packages of dietary supplements per 1 adult, at a cost of approx. PLN 100. A total of nearly 30,000 dietary supplements have been entered into the Register of the State Sanitary Inspection since 2007. According to the European Commission's statistics, Polish dietary supplements market in 1997-2005 has grown by $219 \%$ which was the highest growth among all EU Member States [3]. In 2016 alone, nearly 7,400 notifications of marketing or intended first marketing of dietary supplements were filled with the Register of the State Sanitary Inspection, giving over 600 notifications per month on average [3].

This market in Poland is expected to be growing by around $8 \%$ per year in 2017-2020, and out-ofpharmacy sales is bound to be changing more rapidly with fewer legal restrictions [2]. Management of dietary supplements manufacturing companies in Poland believe that the greatest potential for development lies in preparations for athletes, slimming and libido supporting formulations, supplements helpful in prevention and treatment of influenza and common cold, as well as vitamins and minerals. Food supplements are defined as foodstuffs and are concentrated sources of vitamins, minerals, or other substances with a nutritional or physiological effect. Their intended use is to supplement a regular diet, alone or in combination. They are marketed in a form facilitating dosage (as: capsules, tablets, pellets, or other similar forms; powder sachets, liquid ampoules, dropper bottles, and other similar forms of liquids and powders to be used in small, measured units, except from medicinal product defined by the Medicinal Product Law [4-7]). As it was emphasized by Baraniak et al., dietary supplements are intended to be used as complementary products in a regular diet of healthy individuals, i.e. consumers. Hence, they are not intended for diagnosing, mitigating, preventing, or treating diseases [5]. The widespread use of supplements may be due to the conviction that they are effective in preventing diseases and safe to use. Frequently, however, there is no awareness of fundamental differences between dietary supplements and medicines. Note that dietary supplements often contain - in addition to vitamins and minerals - such ingredients as amino acids, fatty acids, fiber, probiotic microorganisms, honey, and enzymes, but also crude plant material and herbal extracts, including those used in phytotherapeutic medicines.

Horsetail has a long history of use as an anti-inflammatory remedy. Horsetail herb is the common name of overground parts of Equisetum arvense L. According to the Committee on Herbal Medicinal Products (HMPC), owing to a long history of use, horsetail herb products may be used to treat superficial wounds but also minor ailments of the urinary tract, as diuretic agents [8]. Used in the form of infusions and poultices, horsetail has an astringent effect, improves skin elasticity and immunity, and regulates permeability of blood vessel walls [9]. Of active compounds, the most important ones for medicinal effect are derivatives of natural phenols (flavonoids and phenolic acids) and mineral compounds, mainly silicon derivatives. Horsetail has been known as a remineralizing agent, helping retain skin elasticity, preventing skin ageing, nail brittleness, and hair loss. It is widespread in cosmetic industry [10].

Garlic (Allium sativum) is used especially in the treatment of respiratory and immune system diseases. Pharmacological properties of garlic preparations are associated with the presence of sulfur-containing compounds (allicin, allin) and flavonoids (quercetin, rutin) [11]. That is why it is important to determine the content of active compounds in the product, which should be different for herbal drugs and dietary supplements (as defined).

Panax ginseng has been known as one of the most 
widely used herbal remedies. It is commonly used as a stimulant, tonic, diuretic, and digestive aid. Its active compounds, such as saponins (called ginsenosides), polysaccharides, flavonoids, and volatile oils, are responsible for its pharmacological properties. Generally, ginseng's saponins seem to be crucial for physical and mental performance as well as providing resistance to stress and diseases [12]. Furthermore, Ginkgo biloba has antioxidant and neuroprotective effects. What is most important, it contains flavonol glycosides and terpene lactones (ginkgolides A, B, $\mathrm{C}$ and bilobalides) which may be useful in the treatment of Alzheimer's disease and cognitive impairment. Moreover, G. biloba has an anti-platelet effect and may cause interactions with drugs such as warfarin, aspirin, or garlic and ginseng preparations [12]. It is known that some herbal ingredients are primarily used as herbal medicines. It is important to highlight the difference between herbal drug and a food supplement. What is interesting, there are no special restrictions on minimum or maximum quantities of herbal material in food supplements [5].

Food supplements are used in diet supplementation, especially in convalescence, in excessive physical activity, or other physiological conditions accompanied with nutritional deficiencies [13]. The operator marketing or intending to market dietary supplements is only obliged to inform the State Sanitary Inspection [14]. Moreover, the manufacturer or distributor must label the product as a "dietary supplement" and indicate the recommended daily intake and the name of the nutrient on the package. Detailed requirements for dietary supplements were described by Baraniak et al. [5].

A phenomenon of supplementation is observed mainly among adults aged between 30 and 59, 43\% female and $11 \%$ male, respectively [13]. However, the knowledge on dietary supplements and awareness of differences of OTC drugs and dietary supplements, however, is poor in Polish society. A poll by TNS Polska conducted in 2014 has shown that many people took dietary supplements for "vitamins" (31\%) and "minerals" (8\%), and $41 \%$ of them believed these products to have medicinal properties which they did not have. Also $50 \%$ of respondents believed that dietary supplements are subject to same checks as drugs [15]. The risk of using supplements along with standard therapy is often underestimated. It should be emphasized that supplementation in combination with standard therapy can produce adverse side effects and interactions. Requirements for dietary supplements, including the maximum concentration of vitamins and minerals and their chemical forms, are regulated by the
European Union directives and regulations, and national legislations. Active compounds of plant origin being ingredients of dietary supplements as well as herbal medicines are not so strictly regulated.

In addition, intense advertising and lack of proper communication between patient and doctor fixes false beliefs among consumers. According to the National Television and Radio Broadcasting Council, commercials of health products and drugs (including dietary supplements) constituted $4.6 \%$ of all commercials in 1997. In 2015, on the other hand, nearly one in four commercials advertised these products $(24.7 \%)$, and in the Radio it was nearly $50 \%$ which shows that the number of advertisements in this sector recorded a twentyfold increase while the total number of commercials grew only threefold [16].

Laboratory tests of dietary supplements ordered by the Supreme Audit Office (NIK) have shown that many supplements do not have the characteristics declared by their manufacturers, some are harmful, for instance because of contaminants such as pathogenic bacteria (Enterococcus faecium) and forbidden psychoactive substances [3]. Final conclusions of NIK are that the dietary supplements market in Poland is an area of high health hazard, insufficiently diagnosed and supervised by public authorities responsible for food safety.

The present study was aimed at surveying the opinions of future health care professionals on the need to use dietary supplements, if any, attitude towards these products, and awareness of how to use them safely. These factors directly contribute to demand for such products among patients and potential consumers.

\section{MATERIAL AND METHODS}

The study has been conducted between April and June 2015 (3 months). Surveying method was based on a questionnaire specifically designed for this study by the Department of Preventive Health, Poznan University of Medical Sciences, Poland.

The questionnaire comprised 21 items on following domains: demographic characteristics (age, gender, place of residence, faculty), knowledge about supplements, reasons for using dietary supplements, recall of their use (frequency and quantity).

\section{Study population}

The study surveyed 354 individuals, future health 
care professionals, who will be taking care of patients in various areas of the health care system; of these, 35 were future doctors, 20 dieticians, 20 dentists, 27 pharmacists, 60 nurses, 54 physiotherapists, and 39 public health students. All respondents were selected at random.

\section{Study tools}

The pilot study consisted of 6 participants aged from 22 to 26 , associated with healthcare, similarly to target respondent group. Technical part of the survey consisted of 21 questions: 19 closed-ended questions as an opinion poll and review of the respondents' attitude to dietary supplements, with description of reasons for such an attitude, 1 openended question on the knowledge of the "dietary supplement" definition, and 1 question in the form of a table to verify the knowledge of dietary supplements, based on a complex attitude measurement scale by R. Likert (scale ranging from 1 to 5 points). There were 6 ready response/statement options in the questionnaire; moreover - in order to comply with the principle of adequacy, the scope has been extended by the possibility of the source of knowledge other than those previously given being identified by the respondents themselves. Number of responses provided in the specific answer category by the respondents showed their knowledge of dietary supplements. In order to illustrate the weight and importance of individual responses, mean score was calculated for each of them. The survey contains two types of questions: dichotomous and multiple response options (in this case, that fact was clearly indicated to the respondents). The survey is divided into two sections: section 1 - general opinion poll on dietary supplements, and section 2 - addressed only to those subjects taking such products. The questionnaire was voluntary and anonymous. Descriptive statistical functions were used to analyze the data.

Ethical approval: The conducted research is not related to either human or animal use.

\section{RESULTS}

\section{Study sample characteristics}

The study involved 354 students of Poznan University of Medical Sciences. The study subjects were mostly women ( $80 \%, n=282)$, while men made up $20 \%(n=72)$ of the study population. Students of the Faculty of Health Sciences were the largest group within the study population (62.4\% of all respondents). Graduates of these studies will be setting trends in health behavior in the society; hence, it is important to verify their knowledge and opinion on dietary supplements. The largest group were final year students ( $45.5 \%$ of all respondents). Of the respondents, $38.7 \%$ lived in a city with a population of over 50,000; 139 students (39.3\% of all respondents) lived in a city with a population of less than 50,000 ; and $22 \%$ lived in villages. It has been shown that $83.3 \%$ respondents did not follow any specific diet. Detailed profiles of the respondents are shown in table 1.

In the open-ended question 1, the respondents were asked to define a 'dietary supplement'. According to the legislation in force, dietary supplements are not medicinal products. They are food, defined in the Food and Nutrition Safety Act as a foodstuff, which should be designed to supplement the diet. Only 2 persons $(0.6 \%)$ used the term 'foodstuff' in their answers, and 5 persons (1.4\%) claimed that they are 'food' and added an adjective 'healthy'. Nearly $1 / 4$ of the respondents $(24.3 \%, n=86)$ considered the supplements to be 'vitamins', $8.19 \%(n=29)$ 'minerals', $5.08 \%$ of the subject attributed medicinal properties to them using the expression (drug, medicinal pharmaceutical agent, medicinal product), while $0.6 \%(n=2)$ recognized them as untested foodstuffs. All respondents $(n=354)$ knew exactly that the purpose of using these products is supplementation of the diet.

Then, the respondents were asked whether they believed it was possible to compose a diet without using dietary supplements and to justify their opinion. The results obtained are presented in tab. 2 .

Vast majority $(83.9 \%, n=297)$ of subjects considered a diet without supplements possible or probably possible. Most of respondents justified their opinion saying that a versatile diet/proper nutrition with large amounts of vegetables and fruit is sufficient to provide all the nutrients necessary for proper functioning of a healthy organism. 11.6\% $(n=41)$ of the respondents believed that a diet without supplements was not possible or probably not possible. These persons considered dietary supplements an addition to the daily diet helpful in ensuring proper body functioning or actually indispensable in supporting body functions. $4.5 \%(n=16)$ of the respondents claimed it was hard to say if it depended on health of the given individual. These persons mostly 
decided not to express a clear opinion as they were doubtful about the quality of available food in general.

The question: who should use dietary supplements the most (the respondents could check more than one target consumer group) was most frequently answered as follows: sick people (30.3\%), and the elderly $(29.4 \%)$ - see table 3 .
It was demonstrated that a half of the respondents $(50.6 \%, n=179)$ did not use any supplements and $49.4 \%$ of respondents $(n=175)$ declared they used food supplements - see table 4. Moreover, the frequency of supplements usage was tested. Our study shows that $60 \%$ of the subjects used supplements daily (of which $28 \%, n=49$ several dietary supplements per day) while $16.6 \%$ of respondents

Table 1.

Demographic data

\begin{tabular}{|c|c|c|c|c|c|}
\hline \multirow[b]{2}{*}{ Faculty } & & Women & Men & Total & \\
\hline & & $n=282$ & $n=72$ & $n=354$ & $\%$ \\
\hline \multirow[t]{6}{*}{ Faculty of Health Sciences (FHS) } & Nursing & 60 & 2 & 62 & 17.5 \\
\hline & Physiotherapy & 54 & 17 & 71 & 20.1 \\
\hline & Public Health & 39 & 5 & 44 & 12.4 \\
\hline & Obstetrics & 13 & - & 13 & 3.7 \\
\hline & Electroradiology & 11 & 6 & 17 & 4.8 \\
\hline & Rescue Medicine & 3 & 11 & 14 & 3.9 \\
\hline Faculty of Medicine I (FM I) & Medical & 35 & 22 & 57 & 16.1 \\
\hline \multirow[t]{2}{*}{ Faculty of Medicine II (FM II) } & Dietetics & 20 & - & 20 & 5.7 \\
\hline & Dentistry & 20 & 4 & 24 & 6.8 \\
\hline Faculty of Pharmacy (FP) & Pharmacy & 27 & 5 & 32 & 9.0 \\
\hline \multirow[t]{3}{*}{ Place of residence } & Village & 69 & 9 & 78 & 22.0 \\
\hline & City with a population lower than 50,000 & 109 & 30 & 139 & 39.3 \\
\hline & City with a population higher than 50,000 & 104 & 33 & 137 & 38.7 \\
\hline \multirow[t]{4}{*}{ Year of study } & Second & 24 & 1 & 25 & 7.1 \\
\hline & Third & 40 & 10 & 50 & 14.1 \\
\hline & Fourth & 98 & 20 & 118 & 33.3 \\
\hline & Fifth & 120 & 41 & 161 & 45.5 \\
\hline
\end{tabular}

Table 2.

The ability to compose a diet without food supplements in the opinion of the respondents

\begin{tabular}{|c|c|c|c|c|c|c|}
\hline Opinion of the respondent & FM I & FM II & FP & FHS & Total $(n=354)$ & $\%$ \\
\hline Is possible & 42 & 24 & 20 & 104 & 190 & 53.7 \\
\hline Probably possible & 11 & 13 & 9 & 74 & 107 & 30.2 \\
\hline Hard to say & 1 & 3 & 1 & 11 & 16 & 4.5 \\
\hline Probably not possible & 3 & 4 & 1 & 25 & 33 & 9.3 \\
\hline Is not possible & - & - & 1 & 7 & 8 & 2.3 \\
\hline
\end{tabular}

Table 3.

Consumer groups characteristics according to the respondents

\begin{tabular}{lcccrrr}
\hline Target groups & FM I & FM II & FP & FHS & Total $(n=663)$ & $\%$ \\
\hline Sick people & 30 & 32 & 14 & 125 & 201 & 30.3 \\
Elderly & 31 & 22 & 19 & 123 & 193 & 29.4 \\
Sportsmen & 3 & 7 & 13 & 27 & 50 & 7.5 \\
Pregnant women & 10 & 12 & 15 & 47 & 84 & 12.7 \\
Children & 16 & 7 & 12 & 27 & 84 & 12.7 \\
No one & 3 & 7 & & & 49 & 7.4 \\
\hline
\end{tabular}


were taking supplements once a week, once a month (1.7\%), and occasionally (26.9\%).

The most commonly used food supplements (68.6\% of respondents) were products recommended in illness (to alleviate symptoms and strengthen the immune system) - table 5. Studies have shown that $52.6 \%$ of students used supplements in order to improve the condition of their skin, hair, and nails. More than $1 / 3$ of dietary supplements used were memory- and attention-improving products (36.6\%). 'Other' category was selected by $16.0 \%$ $(n=28)$ of respondents; detailed answers are presented in figure 1.

A more detailed analysis of individual categories of dietary supplements used leads to a conclusion that of skin, hair, and nail regenerating products the one most frequently mentioned was field horsetail with $72.83 \%$ of answers $(n=67)$, and the second most frequently used was biotin with $6.52 \%(n=6)$ of answers. Of products boosting the immune system, rutin received the best result $-48.24 \%(n=41)$ of answers, and fish oil ranked second with $20.00 \%$, $n=17$. Results higher than $5 \%$ were also recorded for shark liver oil - with $8.24 \%(n=7)$, and for garlic $-5.88 \%(n=5)$ of answers. Of memory and attention boosting products, lecithin and omega acids had similar number of answers, at $40.85 \%$ and $38.03 \%(n=29$ and $n=27)$ respectively, ginseng $11.27 \%(n=8)$, and Ginkgo biloba - 9.85\% ( $n=7)$. In the "Other" category, symptom alleviating products have the largest share $(38.89 \%, n=35)$, and nutritional supplements and drinks boosting workout performance $(22.22 \%, n=20)$. All-in-one vitamin complex ranked third in terms of usage frequency with $13.33 \%$ of answers $(n=12)$, and nutritional supplements promoting muscle development also had a result of over 5\%, namely $7.78 \%$. Detailed results are presented in figure 1.

Furthermore, it has been shown that soft and hard capsules were the most commonly used types of supplements ( $80.00 \%$ answers) - table 6 .

The respondents were also inquired about the place where they bought dietary supplements. As a result, $89.14 \%$ of respondents using dietary

Table 4.

The frequency of dietary supplements used among the respondents

\begin{tabular}{|c|c|c|c|c|c|c|}
\hline \multirow{2}{*}{ Frequency } & \multicolumn{2}{|c|}{ Women } & \multicolumn{2}{|c|}{ Men } & \multicolumn{2}{|c|}{ Total } \\
\hline & $n$ & $\%$ & $n$ & $\%$ & $n$ & $\%$ \\
\hline No dietary supplementation & 143 & 79.9 & 36 & 20.1 & 179 & 50.6 \\
\hline Dietary supplementation: & 139 & 79.4 & 36 & 20.6 & 175 & 49.4 \\
\hline More than once & 58 & 41.7 & 20 & 55.6 & 78 & 44.6 \\
\hline Every day & 88 & 63.3 & 17 & 47.2 & 105 & 60.0 \\
\hline More than once every day & 40 & 28.8 & 9 & 25.0 & 49 & 28.0 \\
\hline Once a week & 20 & 14.4 & 9 & 25.0 & 29 & 16.6 \\
\hline Once a week, more than one & 13 & 9.4 & 5 & 13.9 & 18 & 10.3 \\
\hline Once a month & 1 & 0.7 & 2 & 5.6 & 3 & 1.7 \\
\hline Once a month, more than one & - & - & 2 & 5.6 & 2 & 1.1 \\
\hline Occasionally & 39 & 28.1 & 8 & 22.2 & 47 & 26.9 \\
\hline Occasionally, more than one & 5 & 3.6 & 3 & 8.3 & 8 & 4.6 \\
\hline
\end{tabular}

Table 5.

Categories of supplements used by respondents (respondents could choose more than one category)

\begin{tabular}{lrrrrrr}
\hline \multirow{2}{*}{ Categories of supplements } & \multicolumn{2}{c}{ Women } & \multicolumn{2}{c}{ Men } & \multicolumn{3}{c}{ Total } \\
\cline { 2 - 7 } & $n$ & $\%$ & $n$ & $\%$ & $n=175$ & $\%$ \\
\hline Skin, hair, and nails & 79 & 31.1 & 13 & 16.9 & 92 & 52.6 \\
Memory and concentration & 52 & 20.5 & 12 & 15.6 & 64 & 36.6 \\
Immune system & 66 & 25.9 & 19 & 24.7 & 85 & 48.6 \\
Physical condition & 7 & 2.8 & 13 & 16.9 & 20 & 11.4 \\
Muscle development & 2 & 0.8 & 5 & 6.5 & 7 & 4.0 \\
Alleviation of ailments & 26 & 10.2 & 9 & 11.7 & 35 & 20.0 \\
Other & 22 & 8.7 & 6 & 7.8 & 281 & 16.0 \\
\hline Total & 254 & 100 & 77 & 100 & 331 & \\
\hline
\end{tabular}


supplementation $(n=156)$ obtained from pharmacy, $9.14 \%(n=16)$ indicated specialized shops, and $0.57 \%(n=1)$ indicated a gas station.

It was noted that previous experience had the greatest effect on the decision to purchase $(33.88 \%$, $n=104)$, although $17.92 \%(n=55)$ of the respondents trusted in advertisements - table 7.

Knowledge of respondents using dietary supplements ( $n=175$, table 8$)$ on products they were taking was assessed and we found that these respondents knew that such products were designed to supplement the diet with the necessary nutrients (the largest average score of 4.35). Note also that these results corroborate with the answers given to question 1 concerning the definition of dietary supplements. The second largest result (4.02) was obtained for the following statement: "these products are as tested/controlled as drugs, safe for consumers if used in compliance with the manufacturer's recommendations". There were major discrepancies between answers given but $70.9 \%$ of the respondents agreed with this statement. Only less than $1 / 3$ of respondents knew that dietary supplements did not need to have an efficacy documented by the manufacturer

Table 6.

Forms of the most commonly used dietary supplements

\begin{tabular}{|c|c|c|c|c|c|c|}
\hline \multirow{2}{*}{ Form of supplements } & \multicolumn{2}{|c|}{ Women } & \multicolumn{2}{|c|}{ Men } & \multicolumn{2}{|c|}{ Total } \\
\hline & $n$ & $\%$ & $n$ & $\%$ & $n=95$ & $\%$ \\
\hline Soft/hard-shelled capsules & 128 & 82 & 28 & 18 & 156 & 80.0 \\
\hline Tablets, including effervescent tablets & 14 & 64 & 8 & 36 & 22 & 11.3 \\
\hline Sachets & 6 & 38 & 10 & 62 & 16 & 8.2 \\
\hline Other & 1 & 100 & 0 & 0 & 1 & 0.5 \\
\hline
\end{tabular}

Table 7.

Determinants affecting the final choice of dietary supplements

\begin{tabular}{|c|c|c|c|c|c|c|c|c|c|c|c|c|c|c|}
\hline \multirow{2}{*}{ Determinant } & \multicolumn{2}{|c|}{ FM I } & \multicolumn{2}{|c|}{ FM II } & \multicolumn{2}{|c|}{ FP } & \multicolumn{2}{|c|}{ FHS } & \multicolumn{2}{|c|}{ Total } & \multicolumn{2}{|c|}{ Women } & \multicolumn{2}{|c|}{ Men } \\
\hline & $n$ & $\%$ & $n$ & $\%$ & $n$ & $\%$ & $n$ & $\%$ & $n$ & $\%$ & $n$ & $\%$ & $n$ & $\%$ \\
\hline Doctor's/pharmacist's advice & 3 & 8 & 5 & 14 & 0 & 0 & 28 & 78 & 36 & 100 & 28 & 78 & 8 & 22 \\
\hline Friends' opinion & 1 & 3 & 8 & 23 & 2 & 6 & 23 & 67 & 34 & 100 & 31 & 91 & 3 & 9 \\
\hline Own experience & 12 & 12 & 15 & 14 & 12 & 12 & 65 & 62 & 104 & 100 & 80 & 77 & 24 & 23 \\
\hline Scientific reports & 3 & 11 & 5 & 19 & 0 & 0 & 19 & 70 & 27 & 100 & 23 & 85 & 4 & 15 \\
\hline Advertisement & 4 & 7 & 6 & 12 & 3 & 5 & 42 & 76 & 55 & 100 & 47 & 85 & 8 & 15 \\
\hline Price & 6 & 16 & 5 & 13 & 5 & 13 & 22 & 58 & 38 & 100 & 36 & 95 & 2 & 5 \\
\hline Other & 4 & 31 & 5 & 38 & 0 & 0 & 4 & 31 & 13 & 100 & 5 & 38 & 8 & 62 \\
\hline Total & 33 & & 49 & & 22 & & 203 & & 307 & & 250 & & 57 & \\
\hline
\end{tabular}

Table 8.

Knowledge on dietary supplements in study group $(n=175)$

\begin{tabular}{|c|c|c|c|c|c|}
\hline Dietary supplements: & $\mathrm{N}$ & Minimum & Maximum & Average & $\begin{array}{l}\text { Standard } \\
\text { deviation }\end{array}$ \\
\hline Are used to supplement the diet with the necessary nutrients & 175 & 3 & 5 & 4.35 & 0.743 \\
\hline Prevent diseases & 175 & 1 & 5 & 3.31 & 1.221 \\
\hline Treat various ailments & 92 & 1 & 4 & 2.36 & 0.752 \\
\hline $\begin{array}{l}\text { Are products tested / controlled same as drugs, are safe for the } \\
\text { consumer if used in accordance with the manufacturer's instructions }\end{array}$ & 139 & 1 & 5 & 4.02 & 1.154 \\
\hline $\begin{array}{l}\text { Are products unexamined / uncontrolled (in contrast to drugs) and } \\
\text { can be potentially dangerous to consumers }\end{array}$ & 68 & 1 & 5 & 3.46 & 0.842 \\
\hline Cannot be overdosed & 40 & 1 & 5 & 3.37 & 1.019 \\
\hline Other & & - & - & - & - \\
\hline
\end{tabular}


or to be controlled in the same way as drugs (mainly pharmacy students). Nearly half of the respondents (48.0\%) believed that dietary supplements prevented or potentially prevented diseases, only $5.14 \%$ believed them to have medicinal properties, and only $17.1 \%$ believed that dietary supplements could not be overdosed.

In conclusion, our respondents show an unusual level of knowledge on dietary supplements and health promotion issues, but they still need more education on this subject.

\section{DISSCUSION}

Our results show that the knowledge of future healthcare professionals is better than that of the general public in Poland but they still need strong education in this matter. Only $5.08 \%$ of students participating in the study believed that supplements had medicinal properties, while according to TNS Polska poll performed in 2014 [15] 41\% of Polish population believed supplements had such properties. As future doctors, nurses, or pharmacists, they must know that food supplements are not strictly controlled, and a lot of them are of low quality. Moreover, some products contained other ingredients than those listed or contained dangerous substances. What is disturbing is that not all of the respondents are aware that these are untested food products meaning that knowledge of future health care professionals about supplementation (food supplements belong to category of food and regulated by food legislation) is unsatisfactory. Similarly to general public, they believed dietary supplements were subject to the same checks as drugs. Polish Press Agency says that in 2017, organizations associating dietary supplements manufacturers devised a Code of Good Dietary Supplements Advertising Practice in order to systemize and improve standards on how to communicate about, promote, and advertise supplements. Systemization of supplements advertising was expected by the Ministry of Health and other institutions controlling the supplements market, including the Office of Competition and Consumer Protection (UOKiK) $[1,17,18]$. Dietary supplements are very commonly used by students. In our study, around half of the respondents admitted to using them (49.4\%). In 2012, Krejpcio et al. [19] obtained similar results: this tendency was observed in $61 \%$ of students of human nutrition and $47 \%$ of psychology students. In a study by Cieślik et al. [20], 51\% of all youngsters aged 16-18 were using such products.
A study conducted among students of Warsaw University of Life Sciences (SGGW) [21] showed that nearly $60 \%$ of respondents used such products. A study by Lebiedzińska et al. [22] found a slightly lower percentage of people using dietary supplements $-57.5 \%$. Among university students in Warsaw and Tarnów, this percentage was much lower with 38.2\% of the respondents declaring use of supplements [23].

In terms of regular diet supplementation, our results (daily use by $63.3 \%$ of women and $47.2 \%$ of men) were similar to those obtained by Sigłowa et al. [23] who showed that $52 \%$ of students majoring in health and nutrition at Warsaw universities declared using dietary supplements at least once a day. Much lower results were showed by Bieżanowska-Kopeć et al. [24] in their study conducted among students of six universities in Cracow, with regular use of supplements by $11-25 \%$ of students, and by Lebiedzińska et al. [22] among students of medical universities from Gdańsk and Grodno and the Stanislaw Staszic College of Public Administration in Białystok (WSAP). Daily supplementation was declared by $25.8 \%$, $23.1 \%$, and $9 \%$ of respondents, respectively.

In our study, $89.14 \%$ were buying their supplements at pharmacies, $9.14 \%$ at specialized shops, while $0.57 \%$ at gas stations. Opinion poll of the SW Research Market and Opinion Research Agency conducted in 2017 has shown that $65 \%$ of Poles were buying their dietary supplements at pharmacies and only $17 \%$ consulted their doctor or pharmacist. Over $10.4 \%$ of respondents admitted to buying supplements online, at specialized stores or pop-up stores with supplements (6.6\%), supermarkets (6.4\%), herbal shops (4.9\%), convenience stores (3.7\%), and marketplaces (2\%) [1]. According to the President of the Polish Federation of Supplements Manufacturers and Distributors, $90 \%$ of sales of supplements challenged by tests conducted by the Supreme Audit Office (NIK) are those offered online as they are subject to no checks [1].

The respondents usually used dietary supplements for aesthetic reasons, including the wish to improve their physique (condition of skin, hair, and nails), boost their immune system, and boost memory and attention. Krejpcio et al. [19] listed the following reasons for using dietary supplements: physical weakening, cold, supplementing deficiencies of nutrients, as well as the wish to maintain and improve the condition of skin, hair, and nails. Among students of six Kraków universities who added supplements to their diet [24], the largest group were students taking these supplements due to an illness. It should be emphasized that food supplements are not intended to 
treat, diagnose, cure, oralleviate symptoms of illness. It was also noted (as in our study) that more women than men declared using these products [24]. This discrepancy between the sexes was also observed among American students where women used supplements more often and longer than men [25].

Dietary supplements also contain herbal ingredients. We have shown that our group of respondents are also familiar with such products. Supplements used included, among others, horsetail, garlic, ginseng, and Ginkgo biloba.

Educating health care professionals on possible interactions of herbal ingredients with prescription drugs and their effect on laboratory results still seems necessary. Even more so considering the fact that mass advertising of dietary supplements is frequently untrustworthy, and adversely affects public health $[3,26]$. In addition to this, NIK found that competent services only conducted very limited activities to monitor health risks resulting from dietary supplements and propagation of risk factors or to share information on these issues [Responsibilities stipulated in Articles 2, 3.1, and 4 of the Public Health Act]. No regular and efficient educational or informational actions concerning dietary supplements were taken to forge the desired attitudes and health behaviors. Therefore, dietary supplements have started to become a vital part of many people's lives and are seen as an innovative lifestyle element. They are a substitute of a correct and balanced diet and are expected to compensate for lack of exercise, haste, stress, and even malaise [3].

\section{CONCLUSIONS}

Use of dietary supplements is widespread among students. Future health care professionals have a better knowledge on food supplementation than

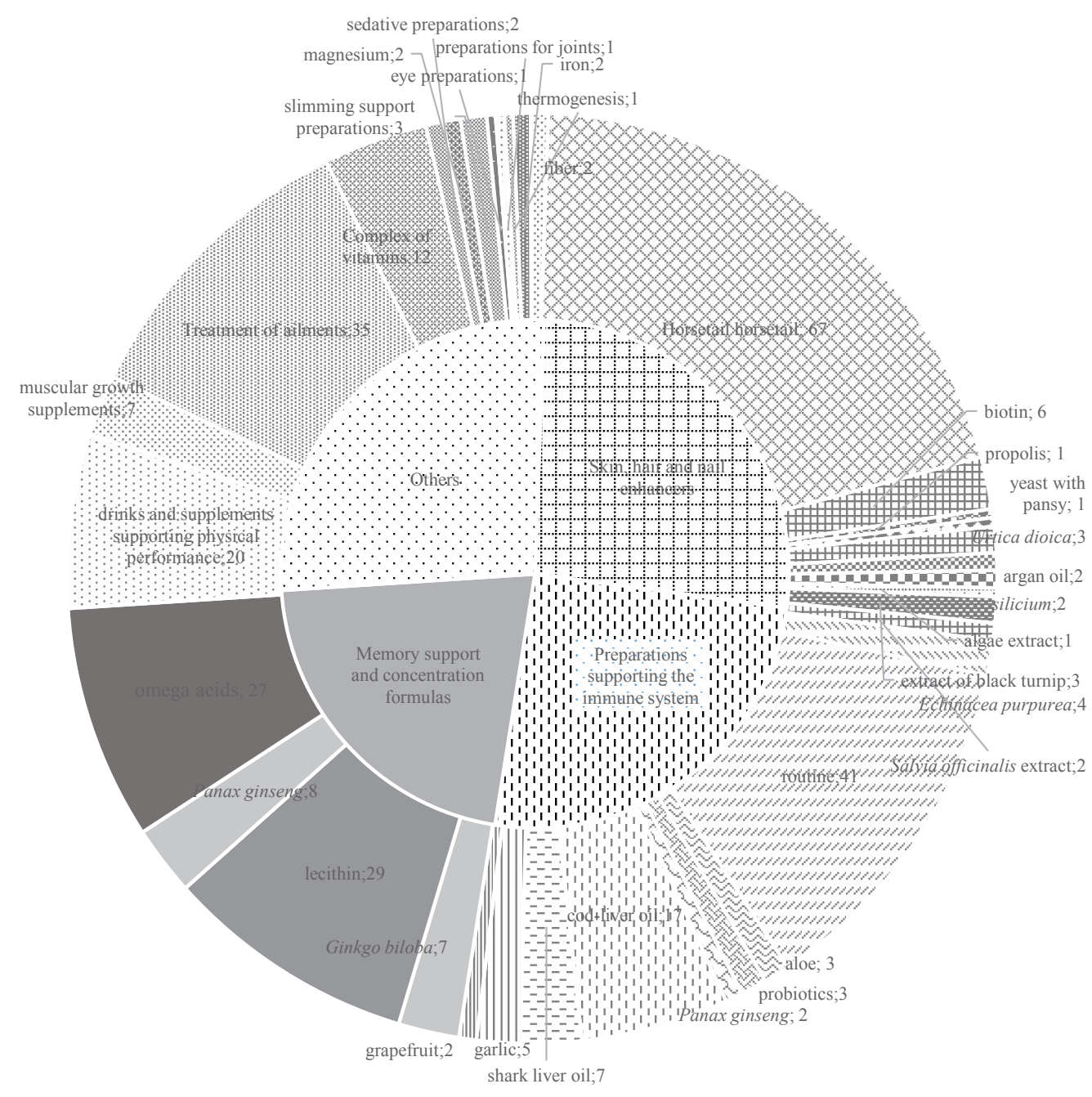

Chart 1.

Products in the appropriate categories of dietary supplements indicated by respondents as applied products. 
population of Poland in general but they still need strong education in this matter. Awareness concerning potential benefits and risks of dietary supplementation is essential for consumer safety [27]. That is why it is important to educate healthcare professionals on food supplements.

Conflict of interest: Authors declare no conflict of interest.

\section{REFERENCES}

1. Polish Press Agency, http://www.pap.pl/aktualnosci/news, 830715,72-proc-polakow-zazywasuplementy-diety.html. (accessed 22.07.2017).

2. PMR. Market of dietary supplements in Poland in 2015. Development forecasts for 20152020. http://www.marketing-news.pl/message. php?art=44892. (accessed 20.07.2017).

3. NIK. 2017. Marketing supplements for dietary supplements. Information on inspection results. https://www.nik.gov.pl/plik/id,13031,vp,15443. pdf (accessed 20.07.2017).

4. Directive 2002/46/EC of the European Parliament and of the Council of 10 June 2002 on the approximation of the laws of the Member States relating to food supplements. Official J Eur Commun L183/51-57.

5. Baraniak J, Kujawski R, Ożarowski M. Law regulations concerning food supplements, dietetic food and novel food containing herbal substances. Herba Pol 2016; 62(4):97-106. doi: http:// dx.doi.org/10.1515/hepo-2016-0025

6. Baraniak J, Kania M. Dietary supplements, foodstuffs for particular nutritional uses and herbal medicinal product in modern phytotherapy. Post Fitoter 2015; 3:177-183.

7. Act of 25 August 2006 on Food Safety and Nutrition, art. 3, Dz. U. 2006 nr. 171, poz. 1225.

8. www.ema.europa.eu/ema/index.jsp?curl=pages/ medicines/herbal/medicines/herbal_ med_000083.jsp\&mid=WC0b01ac058001fa1d. (accessed 12.07.2017).

9. Kulesza B, Kulesza T, Czabak-Garbacz R, Kasprzyk-Kościk B. Support of healing wounds and ulcers. Lek w Polsce 2014; 24(278):12-16.

10. Cisowski W. Field horsetail - medicinal plant. Panaces 2010; 4(33): 5-7.

11. Bogacz A, Karasiewicz M, Kujawski R, Bartkowiak-Wieczorek J, Cichocka J, Kowalska A et al. Molecular mechanisms of regulation of CYP enzymes of phase I metabolism of xenobiotics synthetic drugs and herbal preparations. Herba Pol 2012; 58(3):46-59.

12. Bogacz A, Karasiewicz M, Dziekan K, Procyk D, Górska-Paukszta M, Kowalska A et al. Impact of Panax ginseng and Ginkgo biloba extracts on expression level of transcriptional factors and xenobiotic-metabolizing cytochrome P450 enzymes. Herba Pol 2016; 62(1):42-54. doi: http://dx.doi. org/10.1515/hepo-2016-0004

13. Reguła J, Gramza-Michałowska A, Stachowiak B. Participation of dietary supplements in adult nutrition. Probl Hig Epidemiol 2011; 92(3):614-616.

14. http://suplementy.gis.gov.pl (accessed 10.07.2017).

15. TNS OBOP. Świadome samoleczenie w Polsce 2014. http://centrumprasowe.pap.pl (accessed 15.07.2017).

16. KRRiTv. Report: Embracing trade remittances of health products and medicines in television programs. Dec. 2015. http://www.krrit.gov.pl/Data/ Files/_public/Portals/0/komunikaty/leki-i-suplementy/2015_emisja-przekazow-handlowychproduktow-zdrowotnych-lekow-w-programachtelewizyjnych.pdf (accessed 15.07.2017).

17. Mańka M. The Code of Good Practice is a good move. Farm Prak 2017; 3-4(103):12-13.

18. Code of Good Practice for Advertising of Dietary Supplements. Warsaw 30.11.2016. http://www. polfarmed.com.pl/images/rys/dokumenty_aktualnosci_2016/kodeks.pdf (accessed 15.07.2017).

19. Krejpcio Z, Staniek H, Chmielewska A. Evaluation of the prevalence of dietary supplement consumption in selected groups of students. Probl Hig Epidemiol 2013; 94(3):622-5.

20. Cieślik E, Filipiak-Florkiewicz A, Kopeć A, Bodzioch A, Grzych-Tuleja E. Dietary supplementation with vitamins and/or minerals by young 
people aged 16-18 from the Małopolska region. In: Enriched food and nutraceuticals. Conference of the Małopolska Branch PTTŻ; 2009, June 1819, Kraków 2009:91.

21. Bujko J, Myszkowska-Ryciak J, Nitka I. Evaluation of minerals intake among students of Warsaw Agricultural University. Żyw Człow Metab 2005; 32(1):655-659.

22. Lebiedzińska A, Szpakow A, Hinc A, Fiłon J, Szefer P, Karczewska J. Vitamin and mineral dietary supplements use among Polish and Belarus students [Gdansk, Grodno, Bialystok]. Żyw Człow Metab 2009; 36:55-60.

23. Sigłowa A, Bertrandt B, Conder M, Bertrandt K, Lisiecka A, Kubiak P et al. Diet supplementation among students. Żyw Nau Technol Jak 2009; $4(65): 236-49$.
24. Bieżanowska-Kopeć R, Leszczyńska T, Pisulewski $\mathrm{PM}$. Assessment of the content of folates and other B-group vitamins in the diets of young women (20-25 years old) from the Małopolska region. Żyw Nau Technol Jak 2007; 6(55): 352-8.

25. Spencer EH, Bendich A, Frank E. Vitamin and mineral supplement use among US medical students: A longitudinal study. J Am Diet Assoc 2006; 106:1975-83. doi: http://dx.doi.org/10.1016/j. jada.2006.09.003

26. Hamankiewicz M. The market for supplements needs to be regulated. Puls Farmacji 2014; 4(84):1-4.

27. http://www.cancer.org/treatment/treatmentsandsideeffects/complementaryandalternativemedicine/dietarysupplements/dietarysupplements-risks-and-side-effects.(accessed 10.07.2017).

\title{
Postawa przyszłych pracowników służby zdrowia wobec suplementów diety
}

\author{
EWELINA WIERZEJSKA ${ }^{1}$, JANA KRZYSZTOSZEK ${ }^{2}$, MONIKA KARASIEWICZ ${ }^{1 *}$
}

\author{
${ }^{1}$ Pracownia Zdrowia Międzynarodowego \\ Katedra i Zakład Profilaktyki Zdrowotnej \\ Uniwersytet Medyczny im. Karola Marcinkowskiego w Poznaniu \\ ul. Święcickiego 6 \\ 60-781 Poznań \\ 2Zakład Dydaktyki Wychowania Fizycznego \\ Akademia Wychowania Fizycznego im. Eugeniusza Piaseckiego w Poznaniu \\ ul. Królowej Jadwigi 27/39 \\ 61-871 Poznań \\ *autor, do którego należy kierować korespondencję: : tel. +4861 854 65 75, faks: +4861 85465 78, e-mail: mkarasiewicz@ump.edu.pl
}

\section{Streszczenie}

Wstęp: Stosowanie suplementów diety jest zjawiskiem obserwowanym od wielu lat. Niestety status i główne różnice między tymi produktami a lekami pozostają w dużej mierze nieznane dla konsumentów. 
Cel: Celem pracy była analiza opinii przyszłych pracowników służby zdrowia na temat suplementów diety, ich zachowań w zakresie suplementacji żywności oraz wiedzy na temat bezpieczeństwa tych produktów.

Metody: Badanie zostało przeprowadzone wśród 354 przyszłych pracowników służby zdrowia przy użyciu kwestionariusza składającego się z 21 pytań z zakresu cech demograficznych, wiedzy na temat suplementów, powodów stosowania suplementów diety i wywiadu dotyczącego ich spożycia.

Wyniki: Wszyscy respondenci wiedzieli, że celem stosowania tych produktów jest suplementacja diety. Zdecydowana większość (83,9\%) uważa, że skomponowanie diety bez suplementów jest możliwe lub prawdopodobnie możliwe. 49,4\% respondentów ( $n=175)$ zadeklarowało stosowanie suplementów diety. Najczęściej stosowane $(68,6 \%)$ były produkty zalecane wspomagająco w stanach chorobowych i w celu poprawy stanu skóry, włosów i paznokci. Wśród suplementów diety wskazywanych przez studentów znajdowały się preparaty, które zawierają surowce roślinne, takie jak Equisetum arvense, Allium sativum, Panax ginseng i Ginkgo biloba. Większość ankietowanych kupuje suplementy diety w aptekach (89,14\%).

Wnioski: Korzystanie z suplementów diety jest powszechne wśród studentów. Wiedza przyszłych specjalistów służby zdrowia jest większa niż ogólnej populacji w Polsce, jednak wciąż potrzebują szerokiej edukacji w zakresie statusu suplementów diety.

Słowa kluczowe: suplementy diety, pracownicy stużby zdrowia, surowce roślinne 